\title{
CULTURAL IMPLICATIONS OF TRANSLATION OF COLOMBIAN SPANISH REALIA INTO RUSSIAN
}

\author{
IMPLICAÇÕES CULTURAIS DA TRADUÇÃO DA REALIA COLOMBIANA \\ ESPANHOLA PARA O RUSSO
}

\author{
IMPLICACIONES CULTURALES DE LA TRADUCCIÓN DEL ESPAÑOL \\ COLOMBIANO AL RUSO DE REALIA
}

Olga Gennadyevna PALUTINA ${ }^{1}$ Aliya Rinatovna ISMAGILOVA ${ }^{2}$ Farida Khamisovna ISMAEVA ${ }^{3}$

\begin{abstract}
This article focuses on the methods of translation and interpretation of Colombian Spanish realia into the Russian language on the material of the novels by Gabriel García Márquez. Realia as a linguistic unit is extremely essential in the process of language education, but at the same time causes difficulties with its translation. During the era of international communication and collaboration in many spheres including literature, it is of major importance to adapt some foreign concepts and realia for the receiving cultures. At the Kazan Federal University the students, as future translators, have taken part in a research aiming at analyzing various possibilities of translation and transfer of cultural peculiarities linked to 200 Colombian realia, selected from the works of the famous Colombian novelist. It has been found out that over $94 \%$ of the respondents have faced a problem of understanding the text due to words meaning unknown to the reader. The results obtained feature the most popular ways of rendering the realia meaning employed by the Russian translators.
\end{abstract}

KEYWORDS: Realia. Linguistics. Culture representation. Intercultural communication. Teaching translation.

RESUMO: Este artigo enfoca os métodos de tradução e interpretação da realia do espanhol colombiano para a língua russa a partir do material dos romances de Gabriel García Márquez. A Realia como unidade linguística é extremamente essencial no processo de ensino de línguas, mas ao mesmo tempo causa dificuldades com a sua tradução. Durante a era da comunicação e colaboração internacional em muitas esferas, incluindo a literatura, é de grande importância adaptar alguns conceitos e realia estrangeiros para as culturas receptoras. Na Universidade Federal de Kazan, os alunos, como futuros tradutores, participaram de uma pesquisa com o objetivo de analisar várias possibilidades de tradução e transferência de peculiaridades culturais vinculadas a 200 realias colombianas, selecionadas a partir da obra do famoso romancista colombiano. Verificou-se que mais de $94 \%$ dos respondentes enfrentaram

\footnotetext{
${ }^{1}$ Kazan Federal University (KPFU), Kazan - Russia. ORCID: https://orcid.org/0000-0001-8139-5769. E-mail: opalutina@mail.ru

${ }^{2}$ Kazan Federal University (KPFU), Kazan - Russia. ORCID: https://orcid.org/0000-0002-5970-151X. E-mail: arismagilova@yandex.ru

${ }^{3}$ Kazan Federal University (KPFU), Kazan - Russia. ORCID: https://orcid.org/0000-0003-4496-0700. E-mail: ismaeva.fkh@gmail.ru
} 
problemas de compreensão do texto devido às palavras cujo significado é desconhecido para o leitor. Os resultados obtidos apresentam as formas mais populares de traduzir o significado de realia empregadas pelos tradutores russos.

PALAVRAS-CHAVE: Realia. Linguística. Representação da cultura. Comunicação intercultural. Ensino de tradução.

RESUMEN: Este artículo se centra en los métodos de traducción e interpretación de la realidad española colombiana al idioma ruso sobre el material de las novelas de Gabriel García Márquez. Realia como unidad lingüistica es extremadamente esencial en el proceso de educación de idiomas, pero al mismo tiempo causa dificultades con su traducción. Durante la era de la comunicación y la colaboración internacional en muchas esferas, incluida la literatura, es de gran importancia adaptar algunos conceptos y realidades extranjeros para las culturas receptoras. En la Universidad Federal de Kazán los estudiantes como futuros traductores han participado en una investigación que tiene como objetivo analizar diversas posibilidades de traducción y transferencia de peculiaridades culturales vinculadas a 200 realidades colombianas, seleccionadas de las obras del célebre novelista colombiano. Se ha encontrado que más del $94 \%$ de los encuestados se han enfrentado a un problema de comprensión del texto debido a las palabras cuyo significado desconoce el lector. Los resultados obtenidos muestran las formas más populares de traducir el significado real empleado por los traductores rusos.

PALABRAS CLAVE: Realia. Lingüística. Representación cultural. Comunicación intercultural. Enseñanza de la traducción.

\section{Introduction}

The Spanish language in its all varieties has long attracted researchers all over the world. Its development has been studied from a philosophical viewpoint (ANTONOVA; MYAGKOV; NIKOLAEVA, 2019; MARTÍNEZ; ANTONOVA, 2019), from the point of view of its qualities as a translation language (VASILOVA et al., 2019). The translation of some Spanish realia connected with the Spanish holidays (El Gordo, Nochevieja), food (Turrón, Mantecado) or traditions (El Tío de Nadal) has been investigated (MARTÍNEZ et al., 2017), as well as the rendering of some Russian realia in Spanish (GONZÁLEZ et al., 2020), but the problem of translation of realia belonging to various dialects of Spanish still remains relevant.

By the dialect is understood a language variety delimited in space, in time and in the social structure (OROZCO, 2009). We have selected as the object of our research the realia of the coastal dialect of the Caribbean Sea termed "costeño" due to the fact that the action in many of the novels by Gabriel García Márquez takes place in the northern territories of the country thus making them abound in specific local lexis. 
Based on linguistic-ethnographic Atlas of Colombia (ALEC) Montes identifies a number of sub-dialects, meaning by this concept a set of options formed on the basis of a number of functional standards that distinguish one dialect from another. A sub-dialect is a subdivision of a dialect that is defined by phonetic or morpho-syntactic norms or lexical options (MONTES, 1982).

Montes (1982) singles out the following “costeño" sub-dialects:

$$
\begin{aligned}
& \text { - } \text { Cartagenero, } \\
& \text { - } \quad \text { Samario, } \\
& \text { - } \quad \text { Guajiro, } \\
& \text { - Caribe interior. }
\end{aligned}
$$

The language changes in the sociocultural framework, depending on the region in which it is spoken, the level of cultural education of those who speak it. The process of integrating new words or modifying existing ones is influenced by history, changes in social and political organization.

\section{Methods}

The study used general scientific and private (linguistic) methods. For the analysis there were selected 200 realia from Colombian Spanish used by Marquez in his books and their translations into Russian. Realia is the most interesting unit of translation from the cultural point of view as a unit that contains native national content (FLORIN, 1993). In this paper we tried to find out how important the cultural differences are in the language transmission and in which cases these differences cause problems in language learning or translation. In the course of our research, we conducted a survey of students who study Spanish and Translation at the Linguistics Department. 84 respondents participated in the survey. We found out that $94.4 \%$ of the respondents faced a problem of understanding the text due to the words whose meaning was unknown to the reader. At the same time, 38 people who read the works of Garcia Marquez also replied that they experienced difficulties in reading due to frequently encountered realia.

\section{Results}

There are many models of translation techniques proposed by different linguists, but the model of Vinogradov (2001) is of most interest to us, since it is based on the translation of 
works by Spanish-speaking authors, however, we added elision of realia to this model. The distribution of the translation transformations used by the translators of realia into Russian can be demonstrated by the following diagram.

Figure 1 - Translation transformations used in the Russian version

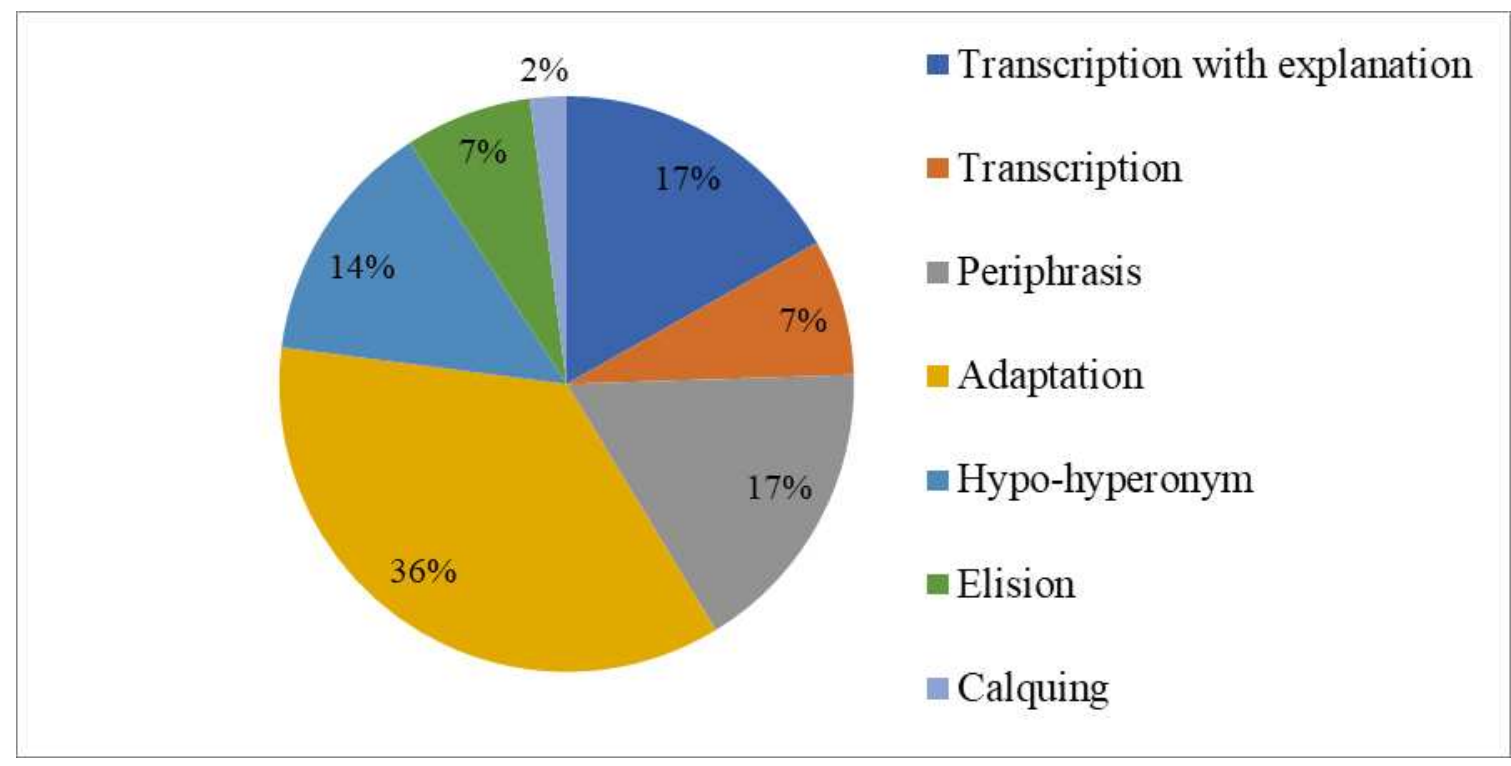

Source: Prepared by the authors

As it turned out, quite a large part (24\%) of the 200 selected realia were translated by the method of transcription. This technique involves word transition from the original language to the target one with maximum resemblance in the phonetic form. As a rule, the translator when seeing the realia in the text has to solve the translation problem: whether to transcribe or to translate? Transcribing means the introduction of a "new" word, so first of all, the translator should make sure that this word has not been previously transcribed, that is, refer to the dictionary of the target language. When transliterating a word from Spanish into Russian, one can create several phonetic versions of the translated realia. According to the data obtained, transliteration was used when translating a quarter of the realia. It is worth considering the fact that this technique is also used for the transferring of toponyms, proper names, so we can talk about the problem of such a translation method. This transformation was mainly used to translate the names of Indian tribes (malanga-malanga), folk dances (manta de bandera-mantade-bandera), animal species (guacamayas-guacamaya) and plants (marimondas-marimonda). The perception of these words is complicated by the fact that the potential reader will not know their meaning, which can lead to difficulties in perceiving the plot. 
If a text does not contain a contextual author's explanation of a realia, the translator's notes with an explanation of the word will be the best way out of this situation.

At the same time, there is no need for notes, when the readers themselves are able to understand the approximate meaning of a realia from the context. Let us take the example of a sentence "[...] while Ursula and the children were bending their backs in the field, taking care of bananas and malanga, cassava and yams, auiyama and eggplants" it can be seen that the four realia translated by transliteration and adaptation are on a par with the objects already familiar to Russian-speaking readers: bananas and eggplants (MARQUEZ, 2016). These words suggest that the realia words in the sentence are the names of cultivated plantfruits. We showed this sentence to the students of the Linguistics Department of KFU. The respondents' opinion on the need to interpret the considered realia was divided: 50 people believe that despite the hint in the context, it is still worth making a note, while 34 respondents do not see the need for this.

Let us consider the transcription of one and the same realia, where in one case the translator adds an explanation to the transcription. Suitable examples are the sentences from the novels "One Hundred Years of Solitude" and "The Autumn of the Patriarch": "When returning with him from the station, Aureliano Segundo lugged away every human being, as if in an impromptu cumbiamba". The realia in this example is cumbiamba, the translators do not give an explanation of this word and its meaning is not clear from the context. Cumbiamba is a Colombian folk Creole dance. Let us consider another example: “...How can I find you in the endless vortex of maranguango and burundango gordolobo and manta-de-bandera in the crowd of taverns". It also lists the names of folk Colombian dances and translators V. Taras and K. Sherman in the second novel give the interpretation in a footnote, which greatly facilitates the reader's perception of the text. Thus, we see how different translators approached the translation of dance names. In this case, we consider the translation from "The Autumn of the Patriarch" to be the most successful.

In order to find out the readers' opinion, we asked the respondents to read the first example and say whether the sentence caused any difficulties. About $58 \%$ of respondents confirmed that an unfamiliar word makes it difficult to understand the sentence, and $33 \%$ of students felt that there is no need to give explanations.

An important role is played by the translation of ethnic communities and related people names. The realia of cachaco can be encountered several times in the works. This name was given to the inhabitants of the capital of Bogota and calling the man "cachaco" meant that he was a native of this city. Since the inhabitants of Bogota used to be considered role models because of their "pure" dialect, this lexeme is synonymous with the adjectives "elegant" and 
"educated". However, the inhabitants of the coast do not just call this name the inhabitants of Bogota but all people living in the Andes, at the mountainous areas. In the novel "One Hundred Years of Solitude", the translator makes a reference to the interpretation of the cachako realia. The work also emphasizes the disapproval shown by the inhabitants of the Atlantic coast towards these people "imagine a power-hungry cachako in a skirt", "in his refined speech, Ursula caught the drawling intonation of the mountain inhabitants- cachako".

In order to deepen our analysis, we classified the realia translated by the considered methods of transformation. Having studied the translation of 48 realia translated by means of transcription, we noticed that they fit the classification of these language units compiled by V.S. Vinogradov. In diagram below you can see its results.

Figure 2 - Realia translated by means of transcription

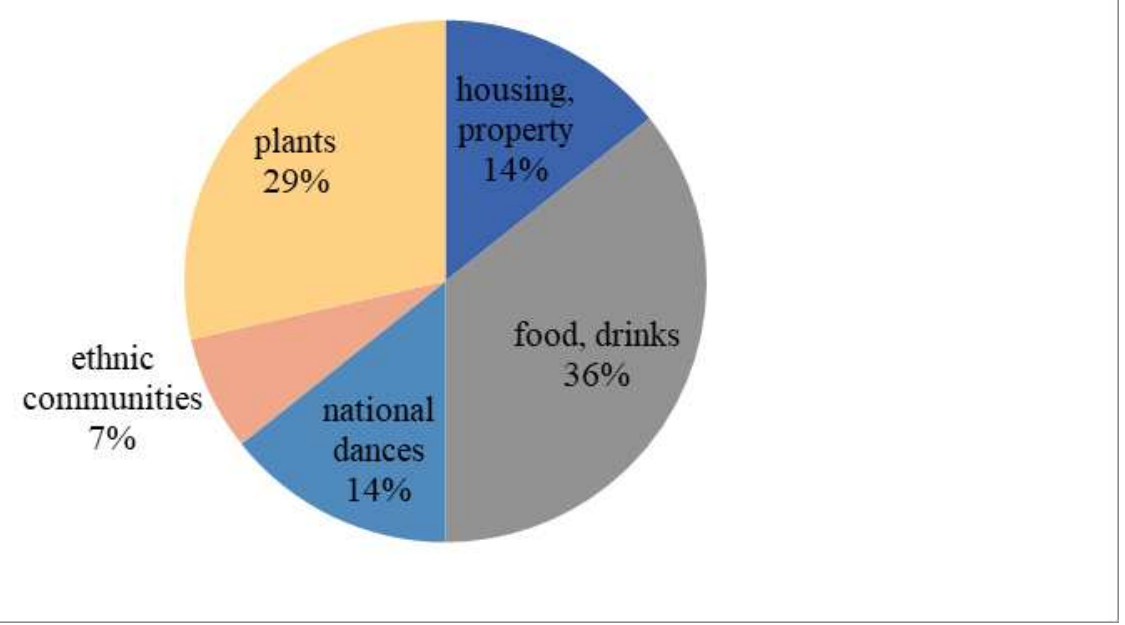

Source: Prepared by the authors

The results of the study show that a significant part of the transcribed realia words belong to category of food and drinks (edible plants were also considered), the realia of plant names come up to $29 \%$, the two realia words naming housing and property, two realia, naming a local dance and one realia, naming a person belonging to an ethnic community.

In the course of our survey, we found out that the readers' opinions on the necessity to comment on the translation were divided. 69 people still prefer to read explanations of words in the book and almost $88 \%$ among them prefer to read the notes at the bottom of the page, while $12 \%$ believe that it is better to make a link to the enclosure at the end of the book.

Thanks to analyzed examples, we can see the difficulties faced by the translator in transcribing and explaining the realia: 
1) the text of the work may be overloaded by national-marked vocabulary, which complicates its perception;

2) frequent notes of the translator may distract the reader from the plot of the novel.

One of the ways to convey the meaning of a realia from the original language to the target one is a descriptive translation or, in another way, a periphrastic translation. This type of transformation helps to solve the problem of overloading the text with exotic vocabulary and, at the same time, allows the reader to get the same information as the reader of the original language. This technique has been used in the translation of 33 realia and it involves the transferring of a realia to another form, that is, its description with the help of familiar words and associations for the culture of the target language. This type of transformation can be considered one of the best when transferring realia, but it requires a lot of skill from the translator.

A considerable part of the realia related to national costumes has also been translated using the adaptation technique. The realia word pollera is found in different dialects and, as a rule, nominates a familiar garment - a skirt. However, depending on the region, the type of skirt changes. On the Caribbean coast of Colombia, these bright long skirts with frills, which are part of folklore, are worn by women to perform cumbia dance and at various carnivals. In novels, this realia is often found, translated as a "skirt", however, for example, in the novel "Love during the Plague", the adjective "frilled" is added to the skirt.

\section{Discussion}

Based on the results of the analysis, the periphrastic technique is one of the best ways of transformation, since the translator can avoid the difficulties when transcribing realia. We have already noted that the translation as close as possible to the original text allows, first of all, to preserve the idea of the author, and, secondly, allows a foreign language reader to get the same information that the original language reader has received. However, this technique is not the most popular among translators. Perhaps this is due to the lack of resources from which to get the necessary information.

As for the elision of realia, it should be noted that this technique can be used in rare cases when an object that nominates a realia is not an important part of culture or life of the readers. 
When choosing translation techniques, it is necessary to consider the semantic meaning of realia, its role in the narration, and also focus on the target reader. The translator should remember that realia carry important cultural information and thanks to them, the atmosphere of the country's life is recreated at a certain point in history, ignoring these language units or incorrect translation indicates that intercultural communication between the author and the reader did not take place.

\section{Summary}

In the course of the transcription and peripheral translation analysis, we came to the conclusion that the use of transliteration can be considered successful when adding an explanation to the transcription. This type of transformation should be used to convey the names of Indian tribes or names of plants, given that the meaning is clear from the context. In its turn, we consider descriptive translation to be the best way to transfer a realia to the target language, since the translator can give a brief explanation of it with the help of three or four words, which will help to establish intercultural communication between the writer and the foreign languagespeaking reader.

ACKNOWLEDGEMENTS: The work is performed according to the Russian Government Program of Competitive Growth of Kazan Federal University.

\section{REFERENCES}

ANTONOVA, N. V; MYAGKOV, G. P; NIKOLAEVA, O. A. Genesis problem of philosophical thought in spanish historiography [Problema de génesis del pensamiento filosófico en la historiografía española]. Utopia y Praxis Latinoamericana, v. 24, n. 5, p. 65$71,2019$.

FLORIN, S. Realia in Translation. In: FLORIN, S. Translation as social action: russian and bulgarian perspectives. London: Routledge, 1993.

GONZÁLEZ, J. M. et al. Peculiarities of gastronomic realias translation on the lessons of the Spanish as a second language. In: INTERNATIONAL TECHNOLOGY, EDUCATION AND DEVELOPMENT CONFERENCE, 14., 2020, Valencia. Proceedings [...]. Valencia, Spain: INTED2020, 2020. p. 2729-2733.

MARQUEZ, G. Sto let odinochestva (One hundred years of solitude). Moscow: ACT Publishing House, 2016. 416 p. 
MARTÍNEZ, I. B. Obstacles in realia translation from the spanish language into the russian language. In: INTERNATIONAL TECHNOLOGY, EDUCATION AND DEVELOPMENT CONFERENCE, 11., 2017, Valencia. Proceedings [...]. Valencia, Spain: INTED2017, 2017. p. 2711-2714.

MARTÍNEZ, P. T, ANTONOVA, N. V. Spanish philosophy: a reality or a myth? Journal of Sociology and Social Anthropology, v. 10, n. 4, p. 209-213, 2019.

MONTES, G. J. J. El español de Colombia: propuesta de clasificación dialectal. Bogota: Istituto Caro y Cuervo, 1982. p. 23-92.

OROZCO, R. El castellano del Caribe colombiano a comienzos del siglo XXI. Revista Internacional de Lingüística Iberoamericana, v. 7, p. 95-114, 2009.

VASILOVA, L. R. et al. Analysis of translation of figures of speech into english, spanish and turkish. Opcion, p. 934-948, 2019.

VINOGRADOV, V. S. Introduction into translation studies (general and lexical issues). Moscow: Institute of general secondary education Publishing house of RAO, 2001. 224 p.

\section{How to reference this article}

PALUTINA, O. G.; ISMAGILOVA, A. R.; ISMAEVA, F. K. Cultural implications of translation of olombian spanish realia into russian. Rev. EntreLínguas, Araraquara, v. 7, n. esp. 3, e021045, Sep. 2021. e-ISSN: 2447-3529. DOI: https://doi.org/10.29051/el.v7iesp.3.15703

Submitted: $10 / 01 / 2021$

Required revisions: 20/03/2021

Approved: $23 / 06 / 2021$

Published: 01/08/2021 